Primljen / Received: 14.11.2011.

Ispravljen / Corrected: 24.4.2012.

Prihvaćen / Accepted: 2.5.2012.

Dostupno online / Available online: 25.5.2012.

\section{Influence of vertical tie columns on bearing capacity of masonry walls}

Authors:

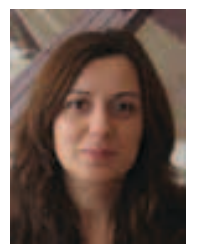

Marija Smilović, B.Sc. CE

University of Split

Faculty of Civil Engineering, Arch. and Geodesy

marija.smilovic@gradst.hr

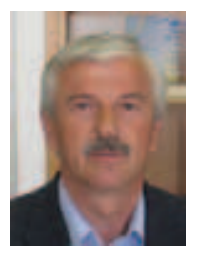

Prof. Jure Radnić, PhD. CE

University of Split

Faculty of Civil Engineering, Arch. and Geodesy

jure.radnic@gradst.hr

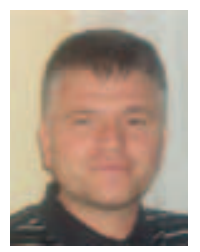

Prof. Alen Harapin, PhD. CE

University of Split

Faculty of Civil Engineering, Arch. and Geodesy alen.harapin@gradst.hr
Original scientific paper

\section{Marija Smilović, Jure Radnić, Alen Harapin}

\section{Influence of vertical tie columns on bearing capacity of masonry walls}

Numerical test results, defining influence of vertical tie columns on the performance of masonry walls subjected to static and dynamic load, are presented in the paper. The analysis focuses on two-storey walls without openings and with openings, with good and poor quality masonry, and with different boundary conditions at the contact between wall foundations and the subsoil. The influence of the profile of longitudinal bars of vertical tie beams on the performance of walls under horizontal static load, and harmonic and seismic acceleration of subsoil, is studied. The numerical model for static and dynamic analysis of in-plane masonry structures, previously developed by the authors, is used in the analysis.

Key words:

masonry wall, vertical tie beam, numerical testing, bearing capacity, static and dynamic load

Izvorni znanstveni rad

Marija Smilović, Jure Radnić, Alen Harapin

\section{Utjecaj vertikalnih serklaža na nosivost zidanih zidova}

U radu su prikazani rezultati numeričkih testova utjecaja vertikalnih serklaža na ponašanje zidanih zidova pod statičkim i dinamičkim opterećenjem. Analizirani su dvoetažni zidovi bez otvora i s otvorima, s dobrim i lošim ziđem, s različitim rubnim uvjetima na spoju temelja zida i podloge. Istražen je utjecaj profila uzdužnih šipki vertikalnih serklaža na ponašanje zidova za horizontalna statička opterećenja te za harmonijska i potresna ubrzanja podloge. $U$ analizi je primijenjen prethodno razvijen numerički model autora za statički i dinamički proračun ravninskih zidanih konstrukcija.

Ključne riječi:

zidani zid, vertikalni serklaž, numerički test, nosivost, statičko i dinamičko opterećenje

Wissenschaftlicher Originalbeitrag

Marija Smilović, Jure Radnić, Alen Harapin

\section{Einfluss vertikaler Ringanker auf die Tragfähigkeit von gemauerten Wänden}

In der Arbeit sind die Resultate numerischer Tests der Einflüsse vertikaler Ringanker auf das Verhalten von gemauerten Wänden unter statischer und dynamischer Belastung dargestellt. Es wurden Doppeletagen - Wände mit und ohne Öffnungen, mit gutem und schlechtem Mauerwerk unter verschiedenen Randbedingungen an den Verbindungen des Mauerfundaments und der Unterlage analysiert. Es wurde der Einfluss von LängsstabProfilen vertikaler Ringanker auf das Verhalten von Wänden bei horizontalen, statischen Belastungen sowie harmonischen und Erdbebenbeschleunigungen der Unterlage erforscht. In der Analyse wurde das vorher entwickelte numerische Modell des Autors für die statische und dynamische Berechnung von ebenen Mauerkonstruktionen angewandt. 


\section{Introduction}

Vertical and horizontal ring beams greatly influence the behaviour and strength of masonry walls under vertical load and especially under horizontal load. Their role is particularly important in cases when masonry structures are subjected to earthquake action. First of all, ring beams connect and stiffen the masonry. They contribute significantly to the strength capacity of masonry structures subjected to compression, bending and shear, both for loads in the wall plane, and loads perpendicular to the wall plane. Ring beams reduce the extent of deformation to masonry. In horizontal activities, ring beams allow formation of diagonal compression in masonry. Vertical ring beams dominantly transfer tensile stresses in masonry. They allow activation of concrete foundations when tension occurs at the wall - foundation interface. Horizontal ring beams redistribute vertical load on the masonry, especially in case of concentrated forces.

Knowledge about the effect of ring beams in masonry structures is mostly qualitative. Although numerous experimental and numerical studies of masonry walls under static and dynamic load have been made (some can be found in [1-20]), studies that quantitatively evaluate the effects of various parameters of vertical and horizontal ring beams on strength capacity and deformability of masonry walls were not available to the authors of this paper.

Using the numerical model for static and dynamic analysis of masonry structures previously developed by the authors [21, 22], this paper investigates the effect of several parameters of vertical ring beams on the behaviour and limit strength of masonry walls. Analyses were performed separately for static and dynamic (seismic) loads. Numerical tests were conducted for a simple wall geometry. Two-storey walls without openings and with openings were considered, with good and poor quality of masonry, and with different boundary conditions at the foundation - base interface. The effect of the profile of longitudinal bars of vertical ring beams on wall behaviour was analyzed. Finally, the most important conclusions of the research were presented.

\section{Brief description of numerical model}

A detailed description of the numerical model adopted for static and dynamic analysis of masonry structures can be found in [21,22], and will be only briefly described hereinafter. The model is intended for simulation of practical planar masonry structures loaded in their plane. The structure can be built of masonry and/or reinforced concrete, and geometry of the spatial structure can also contain subsoil. A simulation of all main nonlinear effects of the behaviour of the masonry, reinforced concrete, and soil, is possible.

A macro or micro model of masonry can be used. In the macro model of the masonry, the complex behaviour of the masonry (masonry units connected by mortar) is modelled by the equivalent material of representative mechanical properties. In the micro model of the masonry, the modelling at the level of masonry units and mortar (joints) is possible, as well as the simulation of connection of mortar and masonry units using contact elements. The isotropic model of masonry can be used, and the use can also be made of the anisotropic model of masonry with different strengths (compressive, tensile, shear), elasticity modulus, shear modulus, and limit strain of masonry in horizontal and vertical directions. The yield and failure of masonry in compression, tensile and shear stiffness of masonry with cracks, and shear failure of masonry, was modelled. The model of fixed orthogonal smeared cracks was used.

The concrete behaviour is simulated with an isotropic material model. The yielding and crushing of concrete in compression, the opening and closing of cracks, as well as the tensile and shear stiffness of cracking concrete, were modelled. The fixed orthogonal crack model, with crack direction corresponding to the direction of principal tensile stresses, was also adopted. The effect of strain rate on mechanical properties of concrete and steel can be simulated through dynamic analyses. Nonlinear effects of reinforcement in compression and tension, with unloading effects, can be simulated.

Material models for masonry or concrete can be applied for soil, based on appropriate material parameters. The geometric nonlinearity of the structure (large displacements) can be simulated.

\section{Effects of vertical ring beams on masonry wall behaviour}

\subsection{General}

The behaviour of masonry walls under load depends inter alia on their geometry (height, width, height and width ratio, the number and location of openings, connection with walls facing the opposite direction, the number and arrangement of ring beams, etc.). Simple geometry of walls was used to analyze the effect of vertical ring beams on the behaviour of masonry walls. Two-storey independent real walls without and with openings were analyzed. The walls are $6 \mathrm{~m}$ high, $3 \mathrm{~m}$ wide, and 0.24 $\mathrm{m}$ thick (Figure 1). All the walls have the same concrete foundation, which is supported by a rigid base. At the floor levels, all the walls were loaded with a constant continuous vertical load q. The weight of the walls, ring beams, and foundation, was directly included in the numerical model.

A macro model of the masonry with isotropic material properties was used. The cases of the so-called good masonry (masonry of high strength, elasticity modulus and shear modulus) and the so-called poor masonry (masonry of low strength, elasticity modulus and shear modulus) were analyzed.

In the static analysis, the wall was loaded with a constant continuous vertical load, and with variable horizontal forces at floor levels. In the dynamic analysis, the horizontal harmonic base acceleration was first applied for all walls. The excitation 
period corresponded to the first period of free elastic oscillations of the corresponding wall.

The resonant harmonic base acceleration was adopted in order to achieve higher levels of nonlinearity. It clearly illustrates the difference between the results obtained by the usual linear model and the adopted nonlinear material model [21, 22]. A dynamic analysis of all the walls was also performed for the Kobe earthquake.

The geometry of the analyzed masonry walls, with reinforcement of ring beams and foundations, is shown in Figure 1.
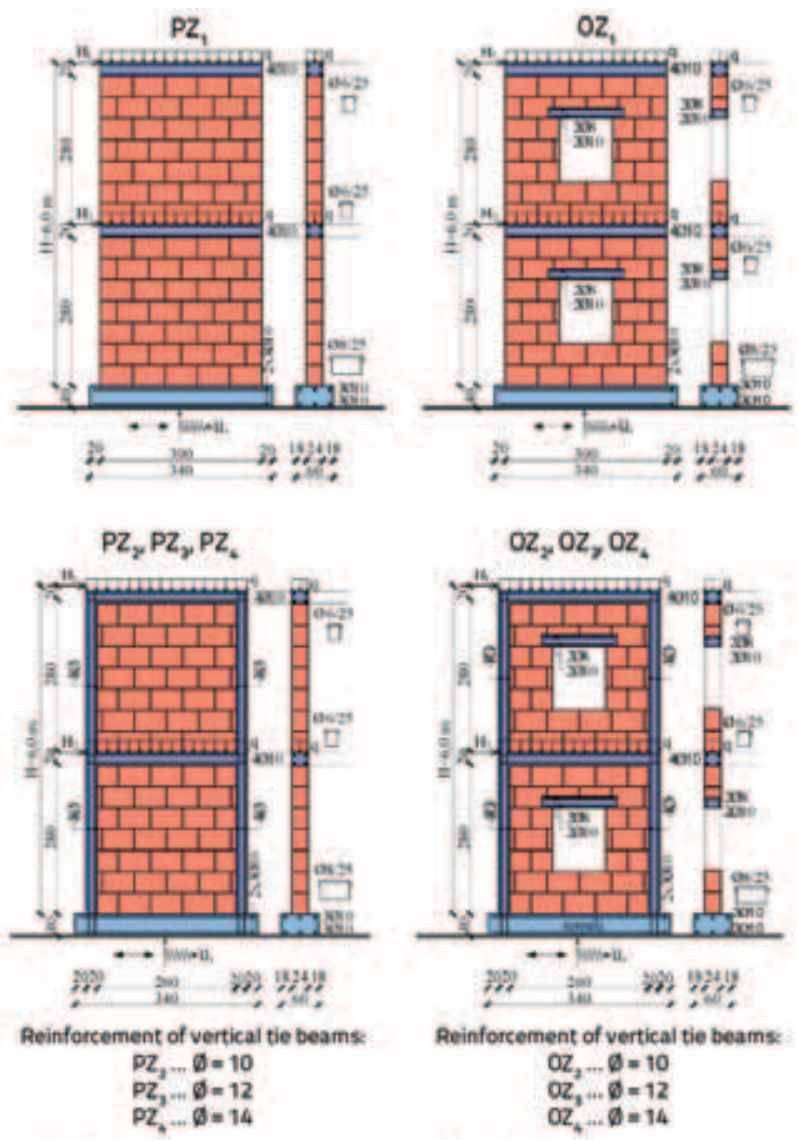

a) Walls without openings

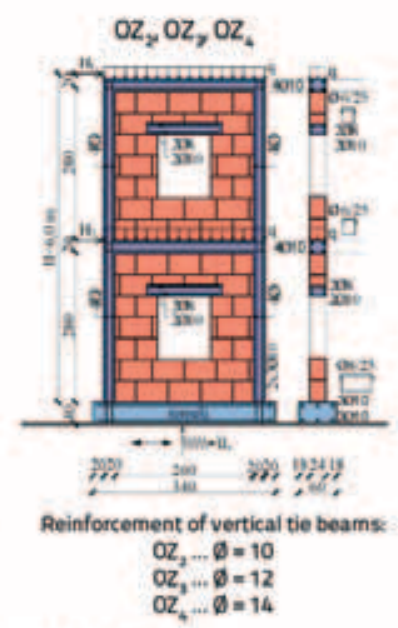

b) Walls with openings

Figure 1. Analyzed masonry walls

The walls without openings (FW), and the walls with openings $(\mathrm{OW})$, have the same horizontal ring beams (longitudinal bars $4 \varnothing 10)$. The walls $F W_{1}$ and $O W_{1}$ do not have vertical ring beams. Walls $\mathrm{FW}_{2}$ and $\mathrm{OW}_{2}$ have vertical ring beams with longitudinal reinforcing bars $4 \varnothing 10$, walls $\mathrm{FW}_{3}$ and $\mathrm{OW}_{3}$ have vertical ring beams with longitudinal reinforcing bars $4 \varnothing 12$, and walls $\mathrm{FW}_{4}$ and $\mathrm{OW}_{4}$ have vertical ring beams with longitudinal reinforcing bars $4 \varnothing 14$. The stirrups of all vertical and horizontal ring beams are $\varnothing 6 / 25$. The effect of transverse reinforcement of ring beams on the behaviour of confined masonry walls was not analyzed. All the walls have the same properties of concrete and reinforcement. Two cases of foundations supported by a rigid surface were analyzed: (i) possible lifting and sliding of foundations, and (ii) prevented lifting and sliding of foundations.

\subsection{Possible lifting and sliding of foundations}

This case corresponds to numerous states of real masonry walls where possible lifting and sliding of foundations have not been prevented. Basic material parameters adopted in numerical analysis are presented in Table 1.

Table 1: Adopted basic material parameters for masonry walls in Item $\mathbf{3 . 2}$

\begin{tabular}{|c|c|c|}
\hline \multirow{2}{*}{$\begin{array}{l}z \\
\vdots \\
0 \\
y \\
\text { I } \\
\Sigma\end{array}$} & $\begin{array}{l}\text { Good } \\
\text { masonry }\end{array}$ & $\begin{array}{l}\mathrm{f}_{\mathrm{m}, \mathrm{c}}=5 \mathrm{MPa} \text { compressive strength } \\
\mathrm{f}_{\mathrm{m}, \mathrm{t}}=0,15 \mathrm{MPa} \text { tensile strength } \\
\mathrm{E}_{\mathrm{m}}=5000 \mathrm{MPa} \text { elasticity modulus } \\
\mathrm{G}_{\mathrm{m}}=1000 \mathrm{MPa} \text { shear modulus }\end{array}$ \\
\hline & $\begin{array}{c}\text { Poor } \\
\text { masonry }\end{array}$ & $\begin{array}{l}\mathrm{f}_{m, c}=1 \mathrm{MPa} \text { compressive strength } \\
\mathrm{f}_{\mathrm{m}, \mathrm{t}}=0,03 \mathrm{MPa} \text { tensile strength } \\
\mathrm{E}_{\mathrm{m}}=1000 \mathrm{MPa} \text { elasticity modulus } \\
\mathrm{G}_{\mathrm{m}}=200 \mathrm{MPa} \text { shear modulus }\end{array}$ \\
\hline \multicolumn{2}{|c|}{$\begin{array}{c}\text { Concrete of } \\
\text { foundation } \\
\text { and ring beams }\end{array}$} & $\begin{array}{l}\mathrm{f}_{\mathrm{c}, \mathrm{c}}=25 \mathrm{MPa} \text { compressive strength } \\
\mathrm{f}_{\mathrm{c}, \mathrm{t}}=2,5 \mathrm{MPa} \text { tensile strength } \\
\mathrm{E}_{\mathrm{c}}=30500 \mathrm{MPa} \text { elasticity modulus } \\
\mathrm{G}_{\mathrm{c}}=13260 \mathrm{MPa} \text { shear modulus }\end{array}$ \\
\hline \multicolumn{2}{|c|}{$\begin{array}{l}\text { Contact elements } \\
\text { under foundation }\end{array}$} & $\begin{aligned} \mathrm{f}_{\mathrm{k}, \mathrm{c}} & =25 \mathrm{MPa} \text { compressive strength } \\
\mathrm{f}_{\mathrm{k}, \mathrm{t}} & =0,0 \mathrm{MPa} \text { tensile strength } \\
\mathrm{E}_{\mathrm{k}} & =30500 \mathrm{MPa} \text { elasticity modulus } \\
\mathrm{G}_{\mathrm{k}} & =13260 \mathrm{MPa} \text { shear modulus }\end{aligned}$ \\
\hline \multicolumn{2}{|c|}{ Reinforcement steel } & $\begin{array}{l}\mathrm{f}_{\mathrm{s}, \mathrm{c}}=500 \mathrm{MPa} \text { compressive strength } \\
\mathrm{f}_{\mathrm{st}}=500 \mathrm{MPa} \text { tensile strength } \\
\mathrm{E}_{\mathrm{s}}=210000 \mathrm{MPa} \text { elasticity modulus }\end{array}$ \\
\hline
\end{tabular}

Spatial discretisation of the walls is shown in Figure 2. A relatively coarse finite element mesh was adopted. At the foundation-soil interface, thin contact element connection of the foundations and the subsoil, thin contact elements were used for an adequate simulation of the lifting and sliding of foundations.

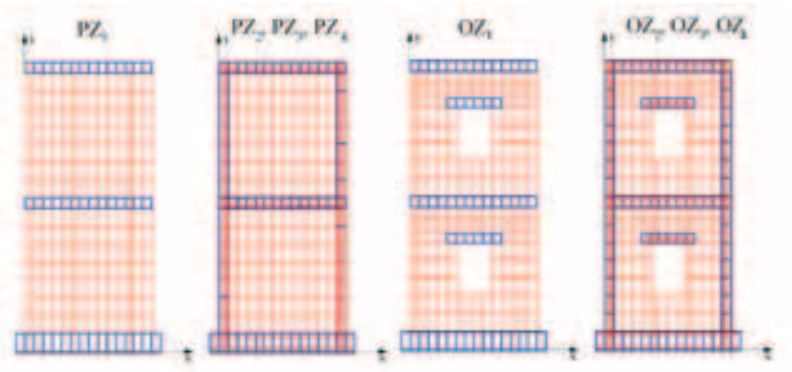

Figure 2. Finite element discretisation of analyzed masonry walls

\subsubsection{Static analysis}

Firstly, the initial state of displacement, stresses and internal forces for the own weight and vertical load $q$ was calculated. 
After that, the walls were additionally loaded with horizontal forces $\mathrm{H}_{1}=\mathrm{H}_{2}$. The load was applied in successive increments until failure.

In addition to numerous other parameters, the strength and deformability of the walls loaded with horizontal load are highly dependent on their vertical load. To illustrate this effect, only the walls $\mathrm{FW}_{2 \mathrm{~g}}$ and $\mathrm{OW}_{2 \mathrm{~g}}$ (g = good masonry) with different vertical loads at the floor level (q): $q_{1}=0 \mathrm{kN} / \mathrm{m}$ (wall self-weight only), $q_{2}=40 \mathrm{kN} / \mathrm{m}$ (wall subjected to medium vertical load), and $q_{3}=80 \mathrm{kN} / \mathrm{m}$ (wall subjected to stronger vertical load), were initially analyzed. The limit strength capacity of the walls depends on the loss of their stability (collapse) as a rigid body. Horizontal wall-top displacement is shown in Figure 3, while reinforcement stresses at points $A$ and $B$ are shown in Figure 4.

As expected, the numerical results show that the walls can withstand small horizontal forces for small vertical loads, because the load quickly leads to the loss of the stability of the wall as a rigid body. In case of large vertical loads, walls are able to withstand greater horizontal forces. Tensile stresses in the longitudinal reinforcement of vertical ring beams are small. In the following examples, where the effect of vertical ring beams on the behaviour of the walls is analyzed, all walls are loaded with $q=40 \mathrm{kN} / \mathrm{m}$ at the floor level.

The effect of vertical ring beams on the horizontal wall-top displacement, for walls without openings, is shown in Figure 5, while the horizontal wall-top displacement, for walls with openings, is shown in Figure 6. It is evident that there is a big difference in the strength capacity and deformability of
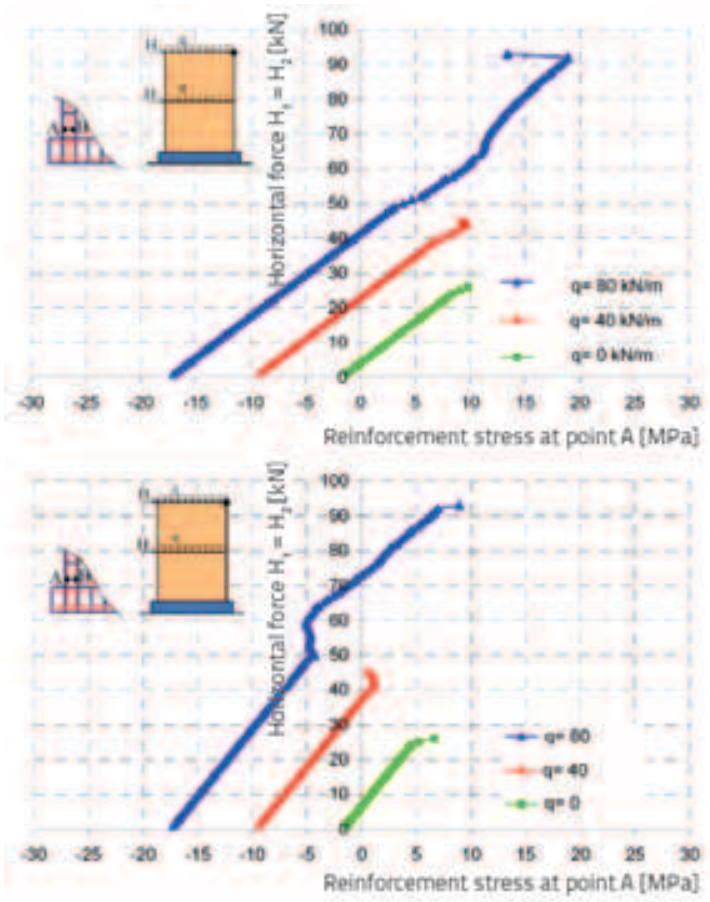

(i) Wall $P Z_{2 \text {, }}$

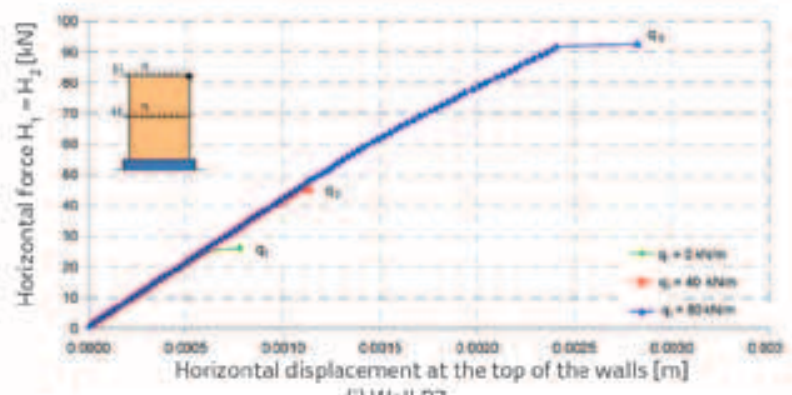
(i) Wall $\mathrm{PZ}$,

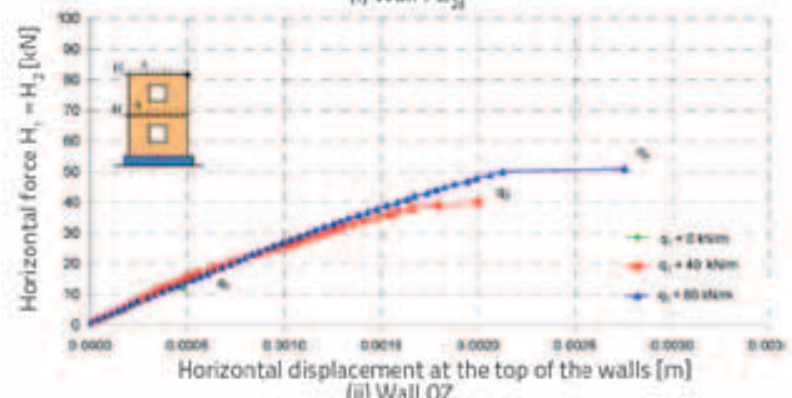

(i) Wall $0 Z$,

Figure 3. Horizontal displacement at the top of the walls $\mathrm{FW}_{2 \mathrm{~g}}$ and $\mathrm{OW} \mathrm{Wg}^{\prime}$ depending on vertical load $q$ - freely supported foundations, static load

vertical walls with no vertical ring beams, when compared to the walls with vertical ring beams. The bar profile of the vertical ring beam has no practical effect on the limit strength of the walls. Specifically, as already indicated, the walls do not have a large vertical load, and their strength capacity is conditioned by the loss of stability of the wall as a rigid body.
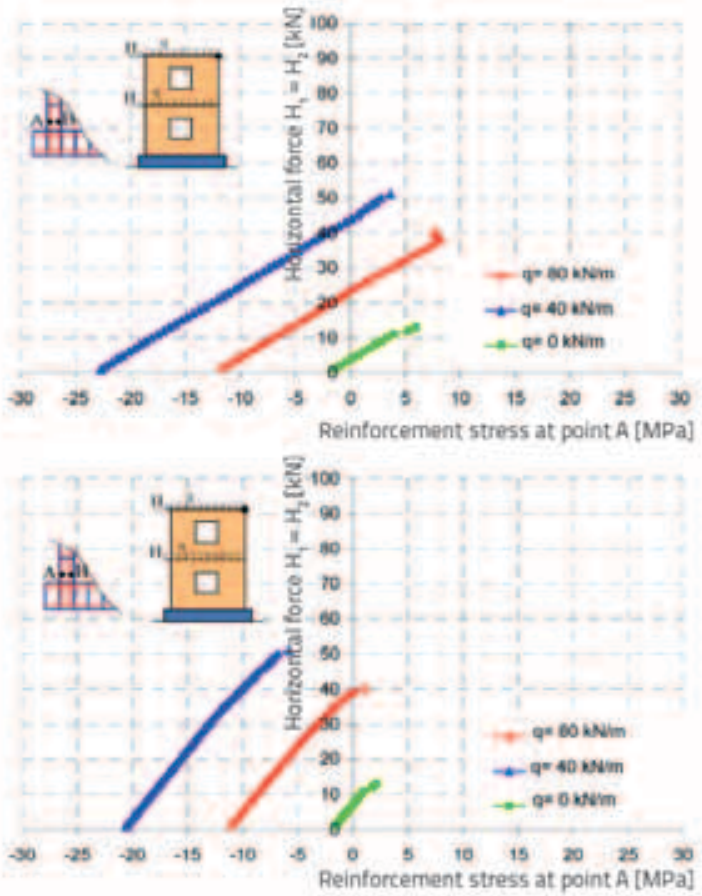

(ii) Wall $0 z_{2}$

Figure 4. Reinforcement stress of vertical ring beams at the bottom of the walls $\mathrm{FW}_{2 \mathrm{~g}}$ and $\mathrm{OW}_{2 \mathrm{~g}^{\prime}}$ depending on vertical load $\mathrm{q}-$ freely supported foundations, static load 


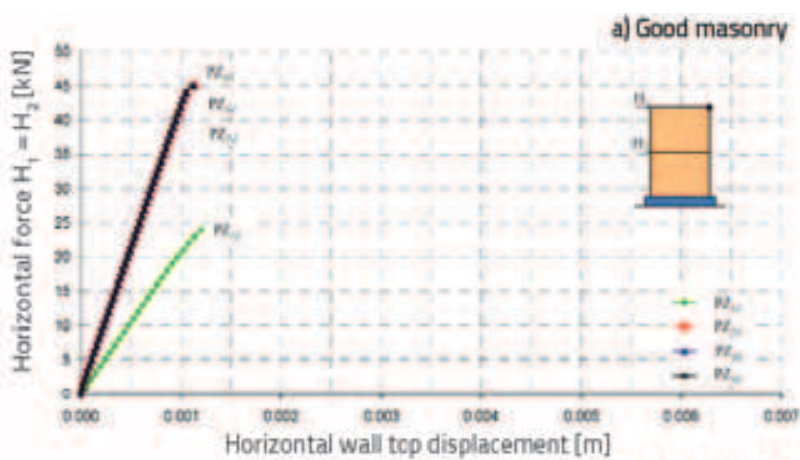

b) Poor masonry

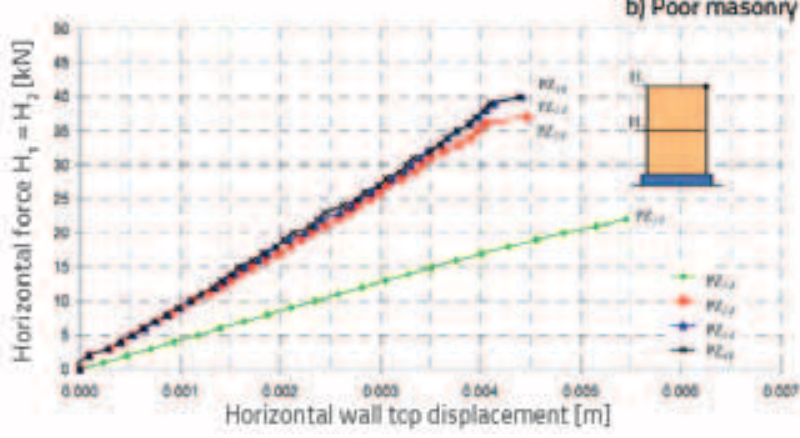

Figure 5. Horizontal wall top displacement for walls without openings - freely supported foundations, static load

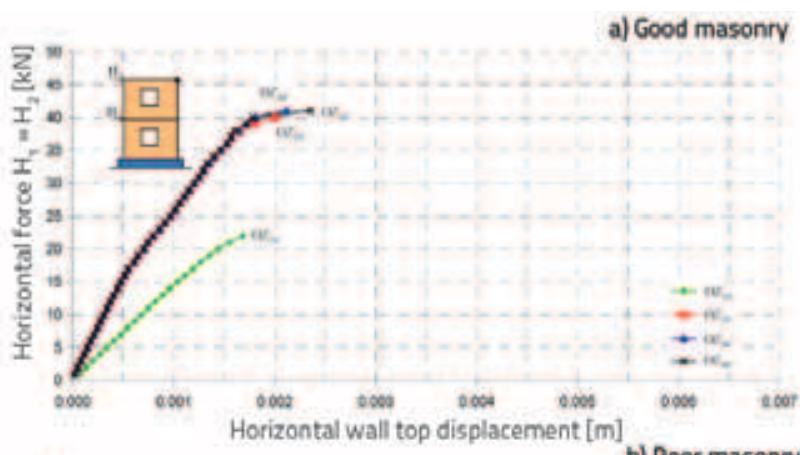

b) Poor masonn

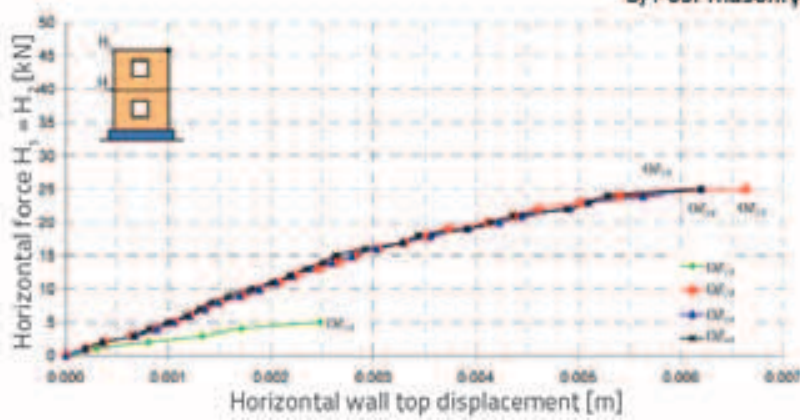

Figure 6. Horizontal wall top displacement for walls with openings freely supported foundations, static load

Deformations of the walls just before failure, with the corresponding state of the cracks, are shown in Figures 7 and 8 . In relation to the walls without openings, the walls with openings have significantly larger deformations and a significantly wider crack zones.
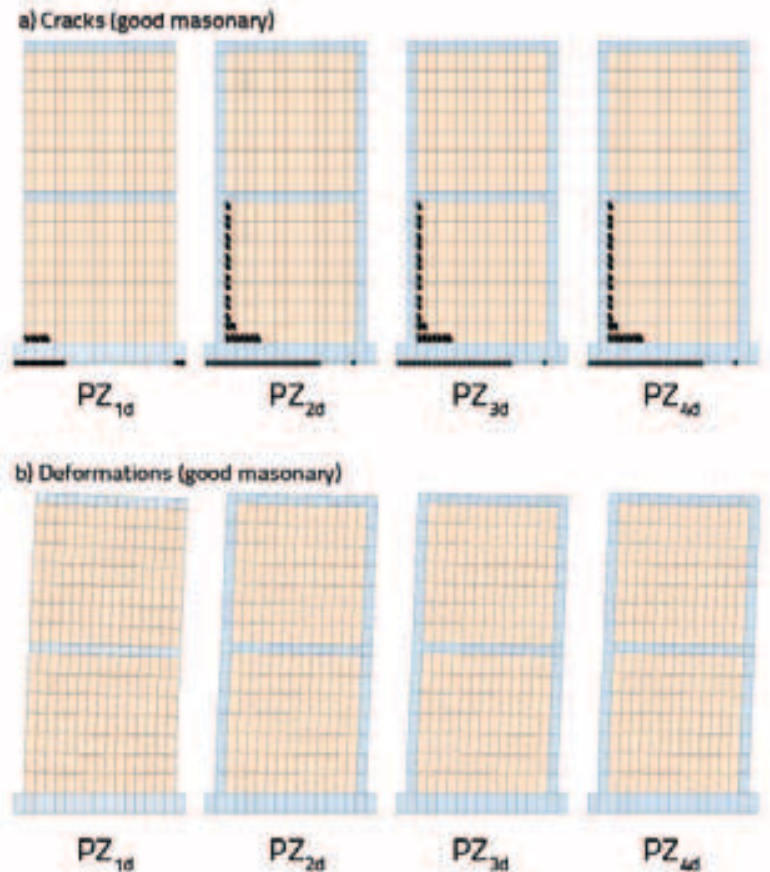

Figure 7. Deformations and cracks in walls without openings (good masonry) before failure - freely supported foundations, static load

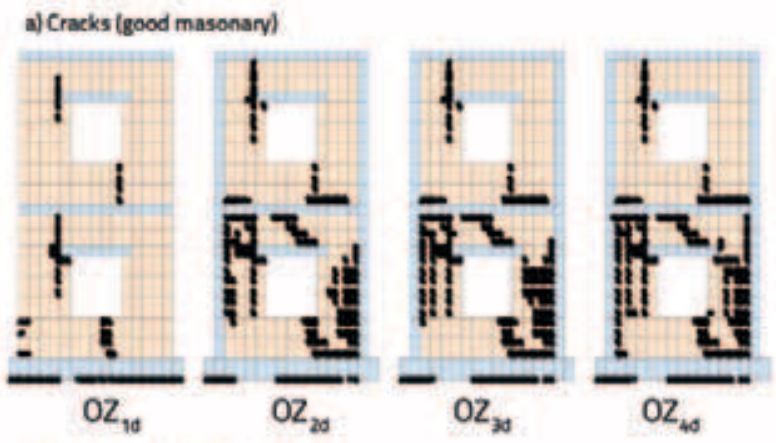

b) Deformations (good masonary)

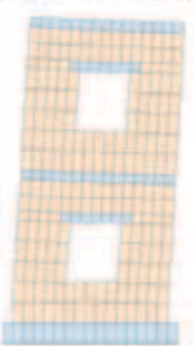

$\mathrm{Oz}_{\text {Id }}$

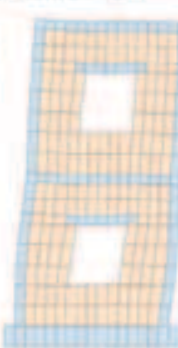

$\mathrm{OZ}_{\mathrm{ad}}$

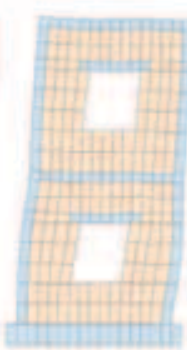

$\mathrm{OZ}_{\mathrm{ad}}$

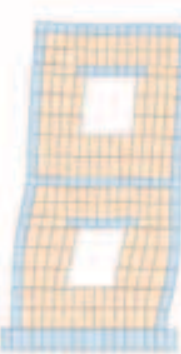

$\mathrm{OZ}_{4 \mathrm{~d}}$
Figure 8. Deformations and cracks in walls with openings (good masonry) before failure - freely supported foundations, static load

The reinforcement stresses of vertical ring beams at the bottom of the walls for the nonlinear model are showen in Figure 9. As previously stated, it is evident that they are low and almost equal for all the profiles of longitudinal bars of vertical ring beams. 

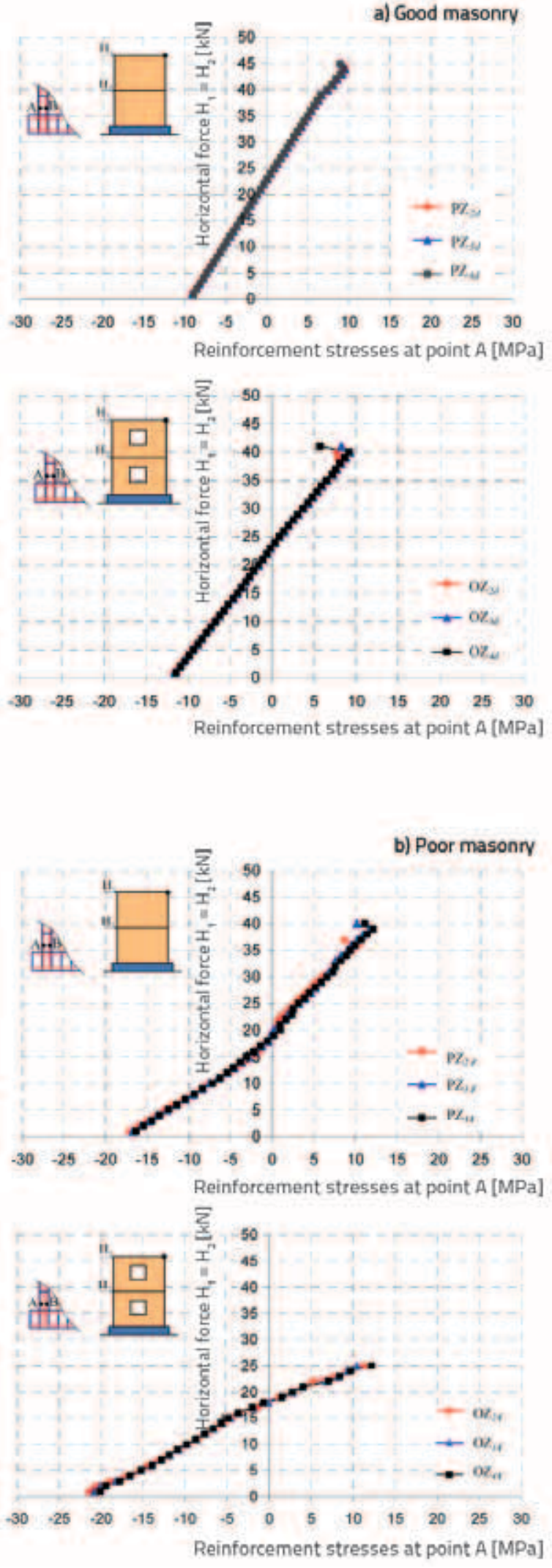

Figure 9. Reinforcement stresses at the bottom of vertical ring beams - freely supported foundations static load

\subsubsection{Dynamical analysis}

The walls analysed in Figure 1 were subjected to constant continuous vertical load $q=40 \mathrm{kN} / \mathrm{m}$. First the eigen problems were solved for every wall and its corresponding stiffness $[21,22]$. The first and second periods of free oscillation of walls are shown in Table 2 . It is evident that the opening in the wall softens the wall, and that the walls without ring beams $\left(\mathrm{FW}_{1}\right.$, called $\left.\mathrm{OW}_{1}\right)$ have significantly higher oscillation periods (lower stiffness) than the corresponding walls with vertical ring beams. The reinforcement of vertical ring beams does not greatly contribute to wall stiffness. Also, a large difference between the first $\left(T_{1}\right)$ and second $\left(T_{2}\right)$ periods of free oscillations of the walls is clearly visible, which is inherent to rigid structures.

In addition to wall analysis by nonlinear model [21, 22], the analysis with linear-elastic material model was also performed so as to illustrate differences in numerical results. A $2 \%$ viscous damping was adopted for all cases.

Table 2. The first (T1) and the second (T2) periods of free oscillation of walls shown in Figure 1

\begin{tabular}{|c|c|c|c|c|c|}
\hline \multirow{2}{*}{\multicolumn{2}{|c|}{ Wall }} & \multicolumn{2}{|c|}{$\mathrm{T}_{1}[\mathrm{~s}]$} & \multicolumn{2}{|c|}{$\mathrm{T}_{2}[\mathrm{~s}]$} \\
\hline & & \multirow{2}{*}{$\begin{array}{c}\begin{array}{c}\text { Good } \\
\text { masonry }\end{array} \\
0,1459\end{array}$} & \multirow{2}{*}{$\begin{array}{c}\begin{array}{c}\text { Poor } \\
\text { masonry }\end{array} \\
0,3239\end{array}$} & \multirow{2}{*}{$\begin{array}{c}\begin{array}{c}\text { Good } \\
\text { masonry }\end{array} \\
0,040\end{array}$} & \multirow{2}{*}{$\begin{array}{c}\begin{array}{c}\text { Poor } \\
\text { masonry }\end{array} \\
0,089\end{array}$} \\
\hline \multirow{4}{*}{ 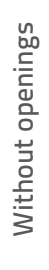 } & $\mathrm{PZ} \mathrm{Z}_{1}$ & & & & \\
\hline & $\mathrm{PZ}_{2}$ & 0,1046 & 0,1771 & 0,0334 & 0,063 \\
\hline & $\mathrm{PZ}_{3}$ & 0,1042 & 0,1767 & 0,0333 & 0,0628 \\
\hline & $\mathrm{PZ}_{4}$ & 0,1037 & 0,1761 & 0,0332 & 0,0626 \\
\hline \multirow{4}{*}{ 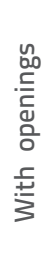 } & $\mathrm{OZ}_{1}$ & 0,1655 & 0,3641 & 0,0506 & 0,1113 \\
\hline & $\mathrm{OZ}_{2}$ & 0,1217 & 0,2122 & 0,0408 & 0,0763 \\
\hline & $\mathrm{OZ}_{3}$ & 0,1213 & 0,2116 & 0,0407 & 0,0761 \\
\hline & $\mathrm{OZ}_{4}$ & 0,1208 & 0,2109 & 0,0406 & 0,0758 \\
\hline
\end{tabular}

\section{Harmonic base acceleration}

The walls were subjected to harmonic base acceleration, as shown in Figure 10. Therefore, the excitation period corresponded to the first period of free oscillations of the elastic wall $\left(\mathrm{T}_{1}\right)$. The maximum base acceleration was $0,2 \mathrm{~g}$, and the excitation period amounted to $7 \mathrm{~T}_{1}$.

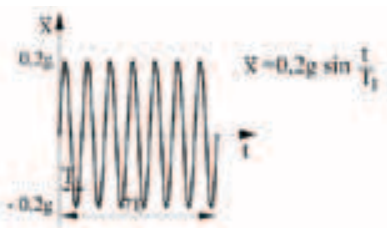

Figure 10. Horizontal harmonic base acceleration adopted in the analysis 
The effect of vertical ring beams on the horizontal wall-top displacement for walls without openings is shown in Figure 11, while horizontal wall-top displacement for walls with openings is shown in Figure 12. It is obvious that the response of the walls with the nonlinear numerical model $[21,22]$ differs completely from the response with a linear-elastic model. The well-known resonant motion of the wall is obtained for elastic behaviour and harmonic base excitation. In nonlinear models, the wall 'falls out" from the resonant motion after the onset of nonlinearity (cracks) in the walls, and after lifting of foundations from the base.

There is also a big difference in maximum displacement of the walls. In nonlinear model, poor masonry walls without vertical
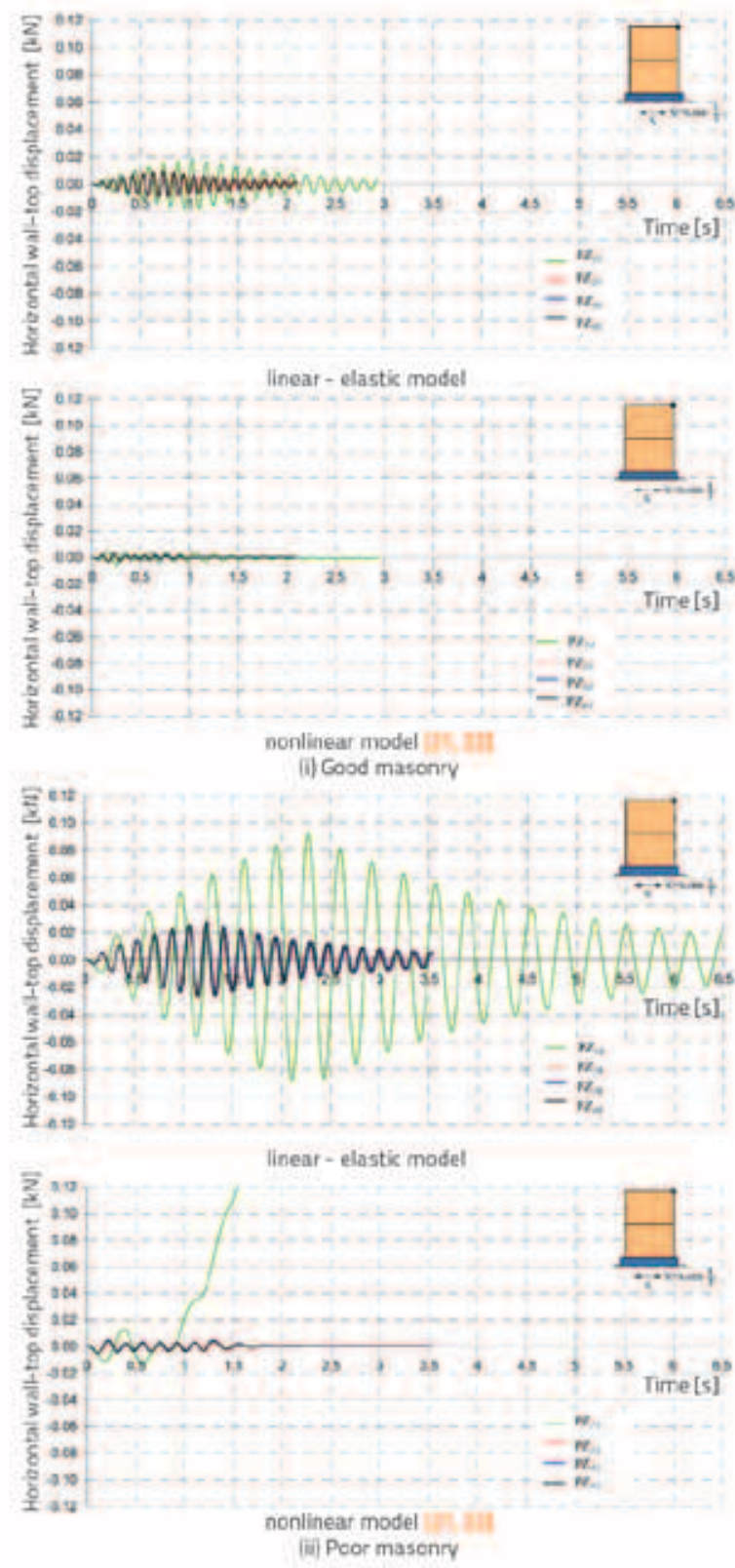

Figure 11. Horizontal wall-top displacement for walls without openings - freely supported foundations, harmonic base acceleration ring beams are harder to collapse. It is evident that the profile of longitudinal bars of vertical ring beams has practically no effect on the response of the wall.

The effect the profile of longitudinal bars of vertical ring beams has on reinforcement stress at the bottom vertical ring beams, for nonlinear model, is shown in Figure 13. It is obvious that, for the corresponding wall geometry and properties of the masonry, the reinforcement stress of vertical ring beams is practically independent of the longitudinal bar profile of the vertical ring beam. Maximum reinforcement stresses are low, which is mostly the consequence of a relatively small total weight of the wall, and lifting of foundations from the base
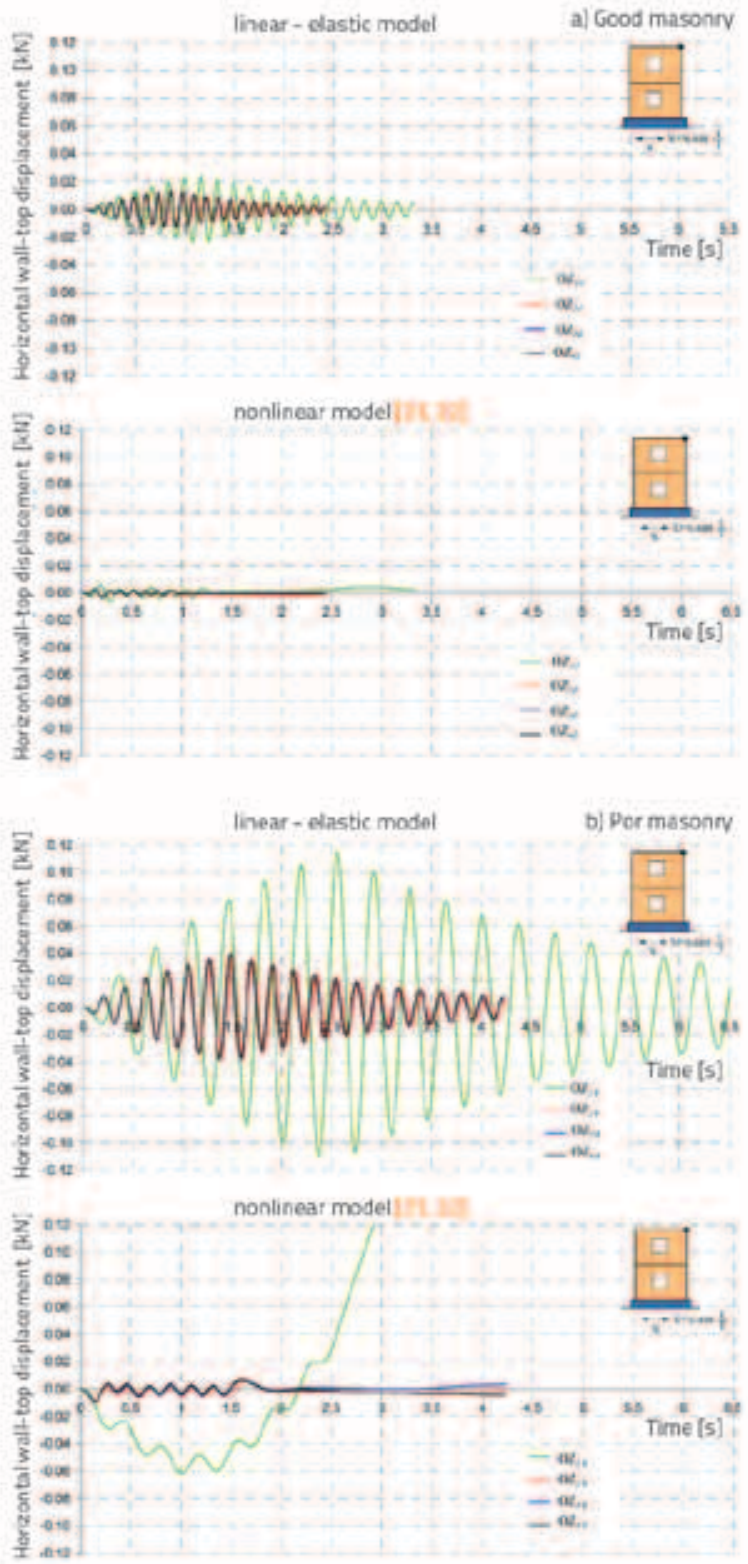

Figure 12. Horizontal wall-top displacement for walls with openings - freely supported foundations, harmonic base acceleration 
during dynamic excitation. The state of cracks in the walls prior to failure is shown in Figures 14 and 15.

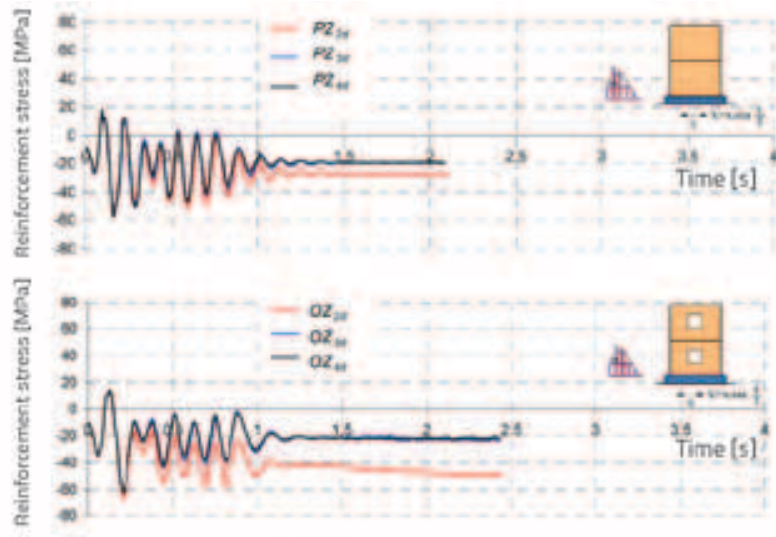

0) God masonry
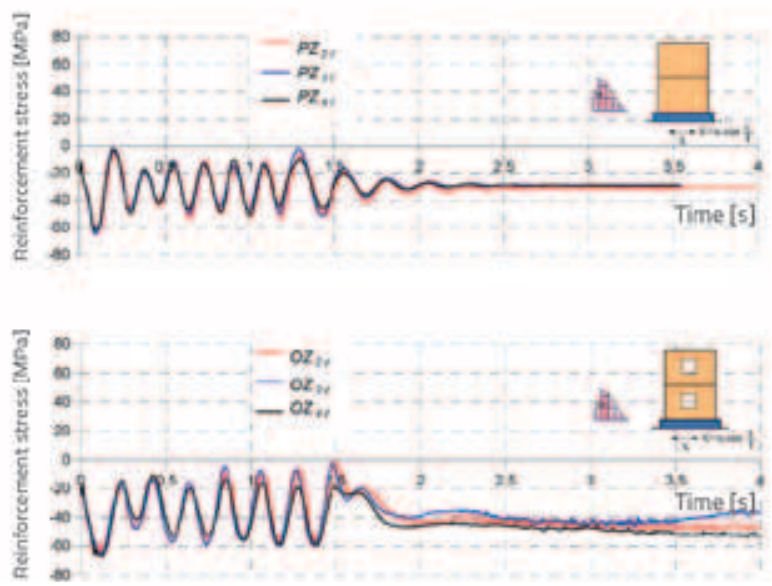

Figure 13. Reinforcement stress at the bottom of vertical ring beams (point A) - freely supported foundations, harmonic base acceleration
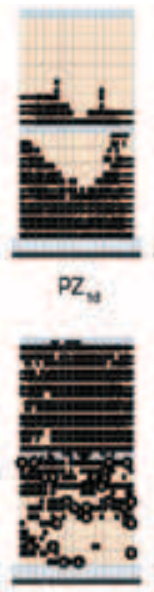

$\mathrm{PZ}_{10}$

- craks Ousting in compression

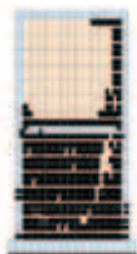

$P Z_{\text {al }}$

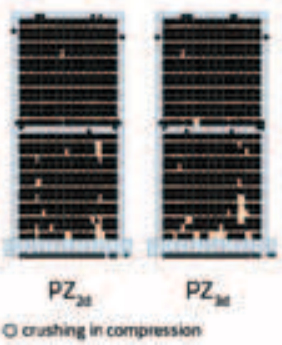

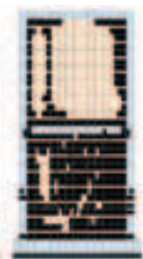

$P Z_{\text {set }}$

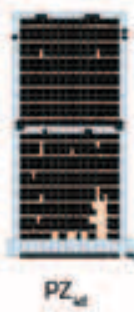

Figure 14. The state of cracks in the walls without openings after base excitation - freely supported foundations, harmonic base acceleration

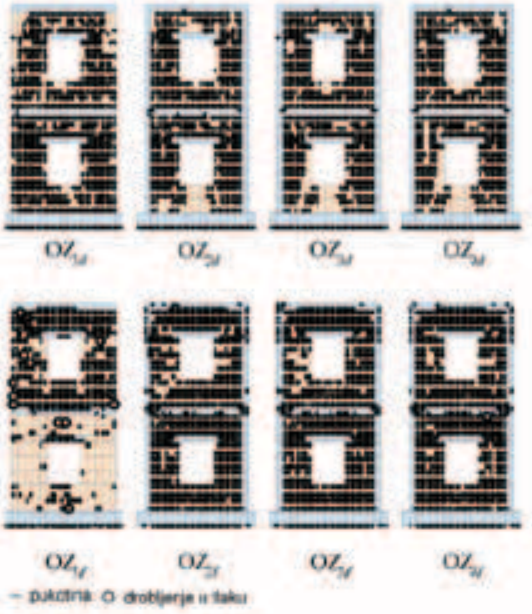

Figure 15. The state of cracks in the walls with openings after base excitation - freely supported foundations, harmonic base acceleration

\section{Seismic base acceleration}

The dynamic analysis was carried out analogously to that presented in Section 3.2.2., using the horizontal acceleration component of the Kobe earthquake (Figure 16) and the nonlinear model only [21,22]. Earthquake amplitudes were scaled, so that the maximum amplitude of acceleration is $0.2 \mathrm{~g}$ (as in the harmonic base excitation).

Some of the numerical results obtained are shown in Figures 17-19. If the values given in these Figures are compared with the corresponding values from Figures 1113 , it can be concluded that the seismic base acceleration is here less favorable than the resonant harmonic base acceleration.

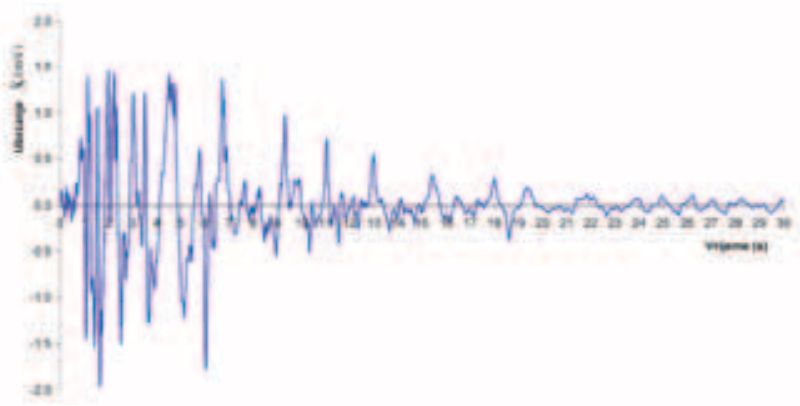

Figure 16. Kobe earthquake (horizontal acceleration component)

\subsection{Prevented lifting and sliding of foundations}

This case corresponds to some real masonry walls where the lifting and sliding of foundations are not possible. In this analysis, the walls from Figure 1 were re-examined, but with prevented horizontal and vertical displacement of the foundation bottom. The vertical load at the floor level was $q=$ $40 \mathrm{kN} / \mathrm{m}$. Only the nonlinear material model was considered according to $[21,22]$. 


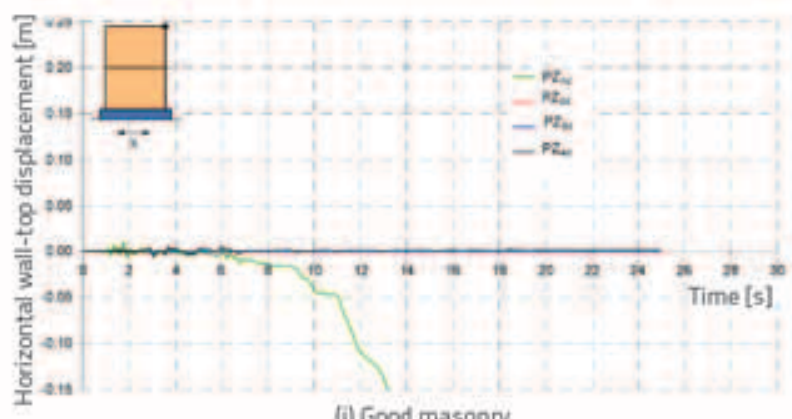

(i) Good masonry

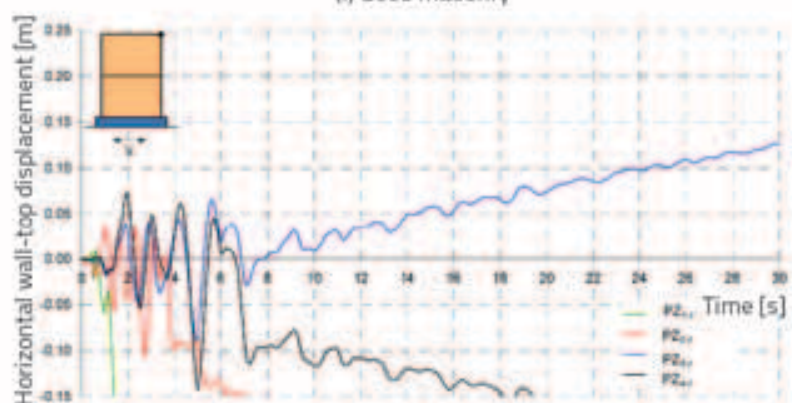

(ii) Poor masonry

Figure 17. Horizontal wall-top displacement for walls without openings - freely supported foundations, seismic activity
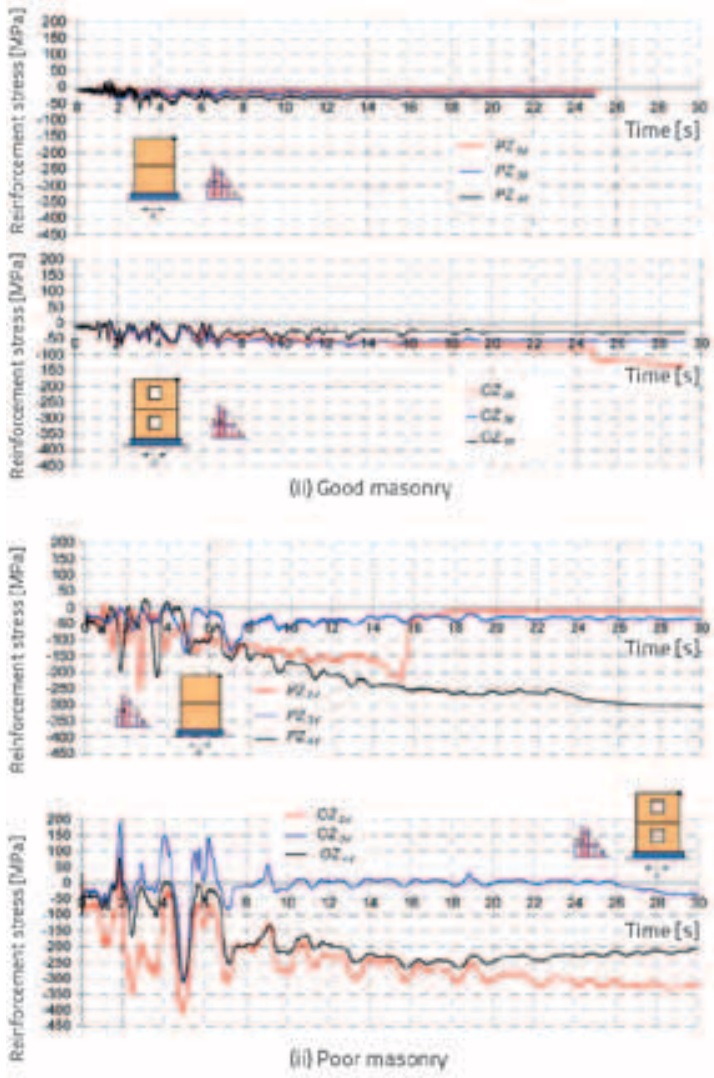

Figure 19. Reinforcement stress at the bottom of vertical ring beams freely supported foundations, seismic activity

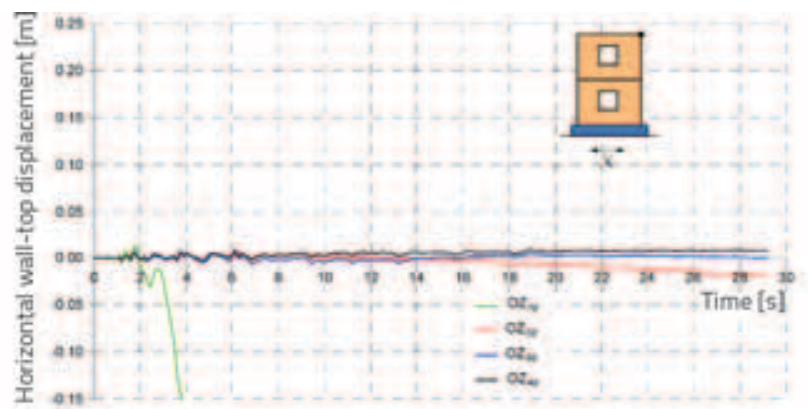

(i) Good masonry

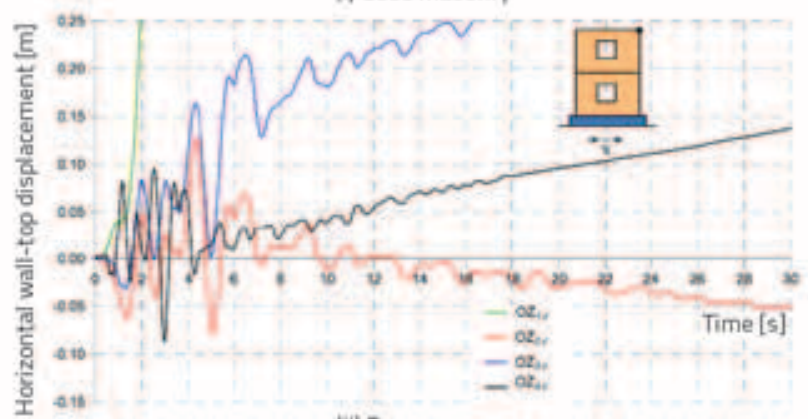

(ii) Poor masonry

Figure 18. Horizontal wall-top displacement for walls with openings - freely supported foundations, seismic activity

\subsubsection{Static analysis}

An analysis analogous to that presented in Item 3.2.1 was conducted. Some of the results obtained during the analysis are shown in Figures 20-24. By comparing the computational values from these Figures with the corresponding values from Figures 5-9, it can be concluded that the wall with prevented lifting and sliding of foundations has a significantly higher limit strength capacity, compared to a similar wall with enabled lifting and sliding of foundations.

The limit strength capacity depends on the strength capacity of the reinforced vertical ring beams (good masonry) or strength capacity of masonry (poor masonry). Here a greater difference can be noted in the limit strength capacity and deformability of the walls without vertical ring beams, when compared to the walls with vertical ring beams. The effect of profile of longitudinal bars of vertical ring beams on the limit strength capacity of the walls is also visible. A significant effect of the quality of masonry on the strength capacity and deformability of the walls can also be observed.

\subsubsection{Dynamic analysis}

A dynamic analysis analogous to that presented in Item 3.2.2 was conducted. It should be noted that the walls with prevented lifting and sliding of foundations also have periods of elastic system according to Table 2 . 


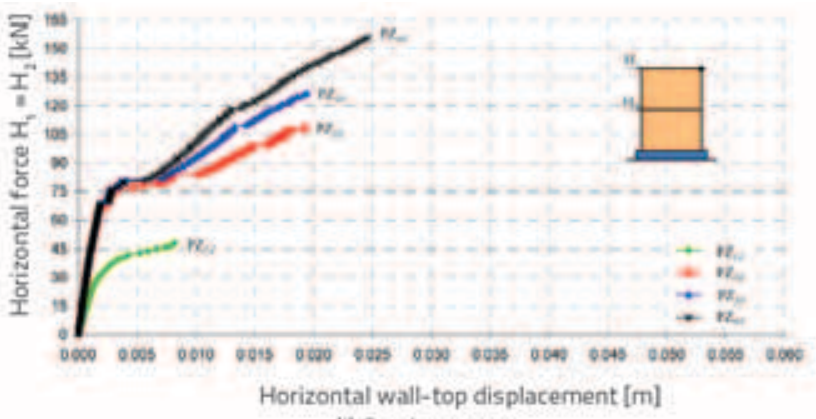

(i) Good masonry

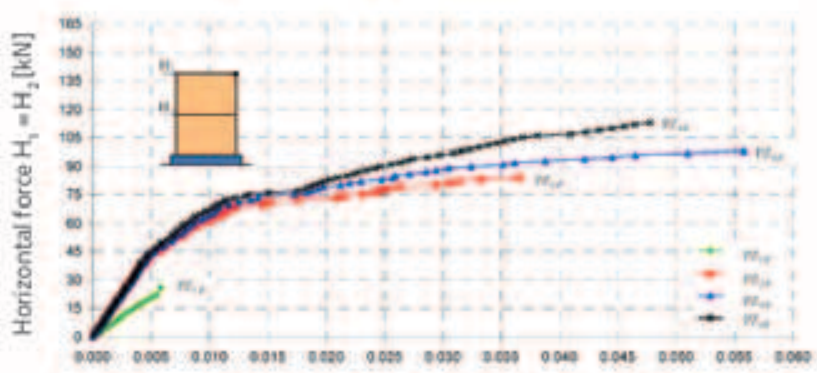

Horizontal wall-top displacement [m]

(ii) Poor masonry

Figure 20. Horizontal wall-top displacemen for walls without openings - fixed foundation, static load

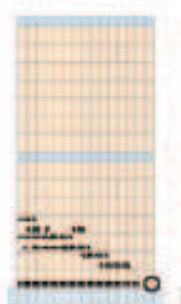

$\mathrm{PZ}_{M}$

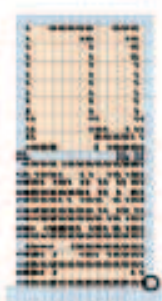

$\mathrm{PZ}$

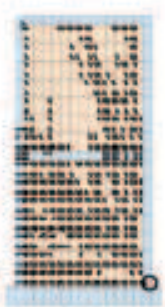

$\mathrm{PZ}_{\mathrm{M}}$

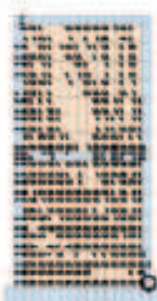

$\mathrm{PZ}_{\text {MI }}$
- craks

o crushing

in compression (i) craks

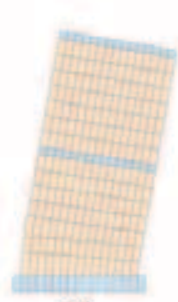

$\mathbf{P Z}$

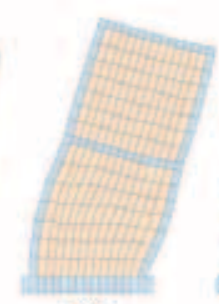

$\mathrm{PZ} \mathrm{T}_{\mathrm{N}}$

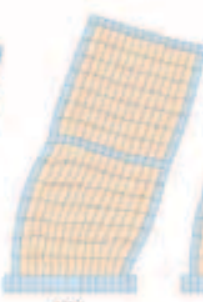

$\mathrm{PZ}$

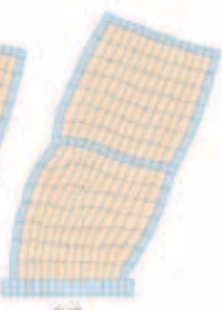

$\mathrm{Pl}$ (ii) Defotmations

Figure 22. Deformations and cracks in walls without openings (good masonry) before failure - fixed foundation, static load

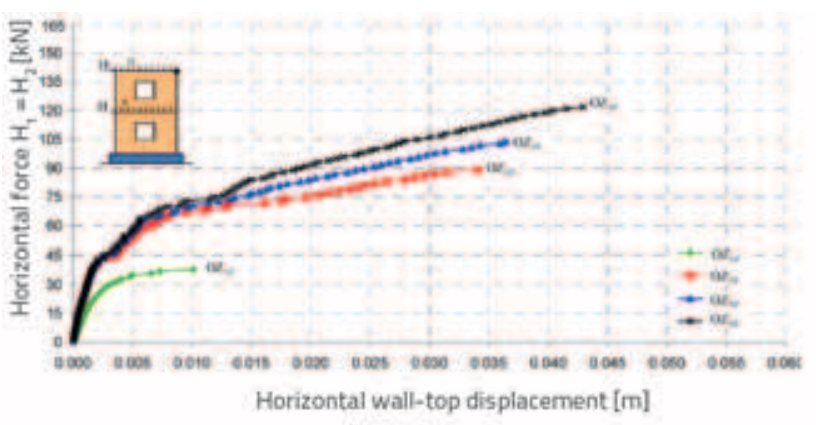

(i) Good masonry

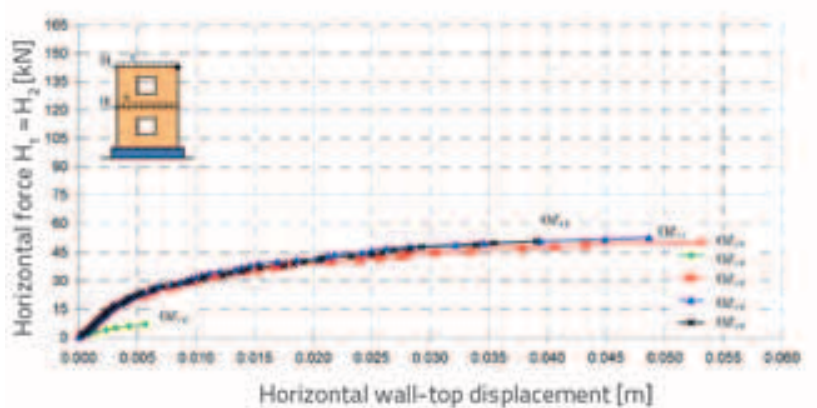

(ii) Poor masonry

Figure 21. Horizontal wall-top displacement for walls with openings - fixed foundation, static load

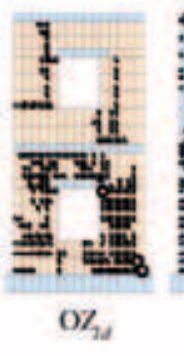

craks
o crushing
in compression

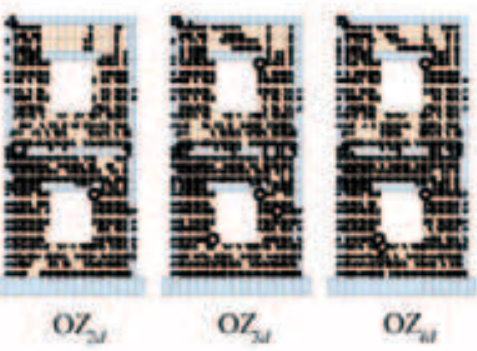

(i) craks
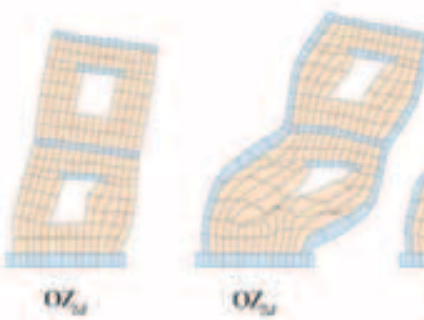

$\mathrm{ov}_{\mathrm{N}}$

$\mathrm{OV}_{2}$

07

(ii) Defotmations

Figure 23. Deformations and cracks in walls with openings (good masonry) before failure - fixed foundation, static load 

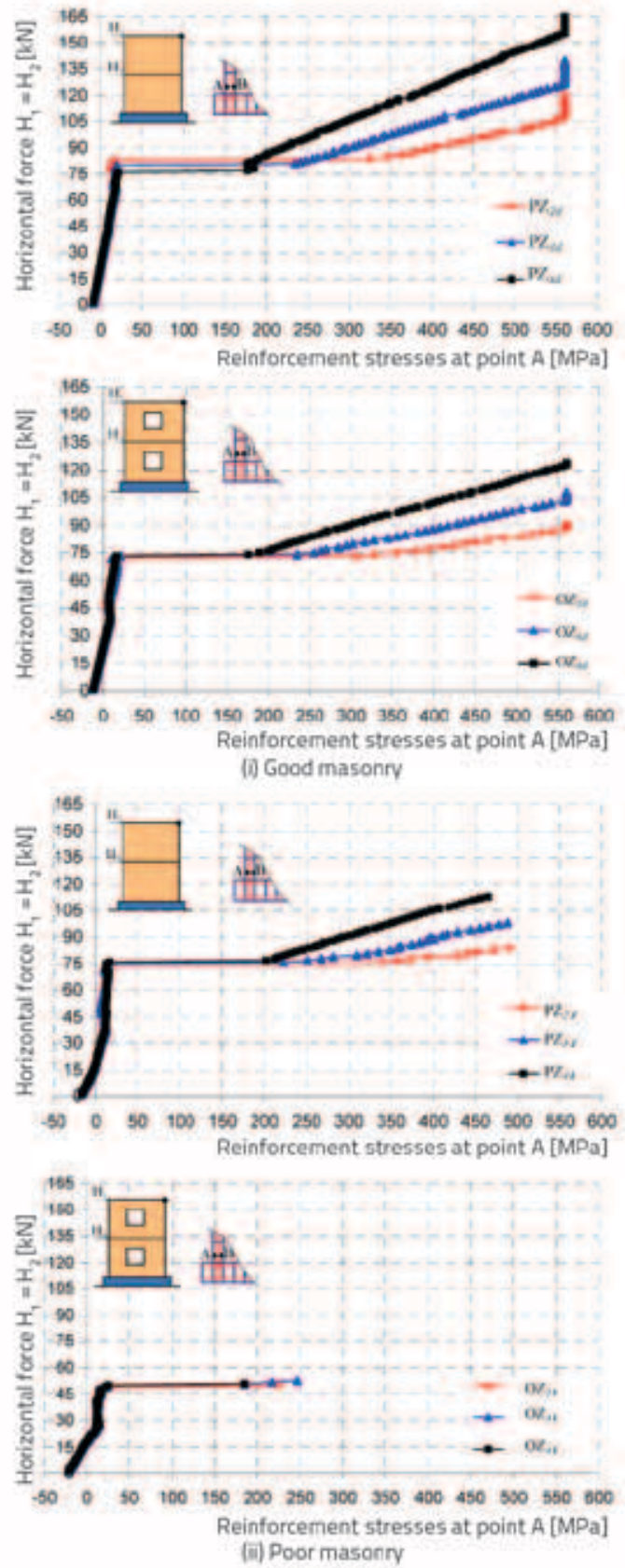

Figure 24. Reinforcement stresses at the bottom of the vertical ring beams - fixed foundation, static load

\section{Harmonic base acceleration}

Some of the results obtained are shown in Figures 25-29. If computational values from these Figures are compared with the corresponding values from Figures 11-15, it can be concluded that these values are similar. For the observed harmonic base acceleration, the wall with fixed foundation behaves similarly to the wall with the lifting and sliding of foundations. The effect of vertical ring beams on reinforcement stress at the bottom of the
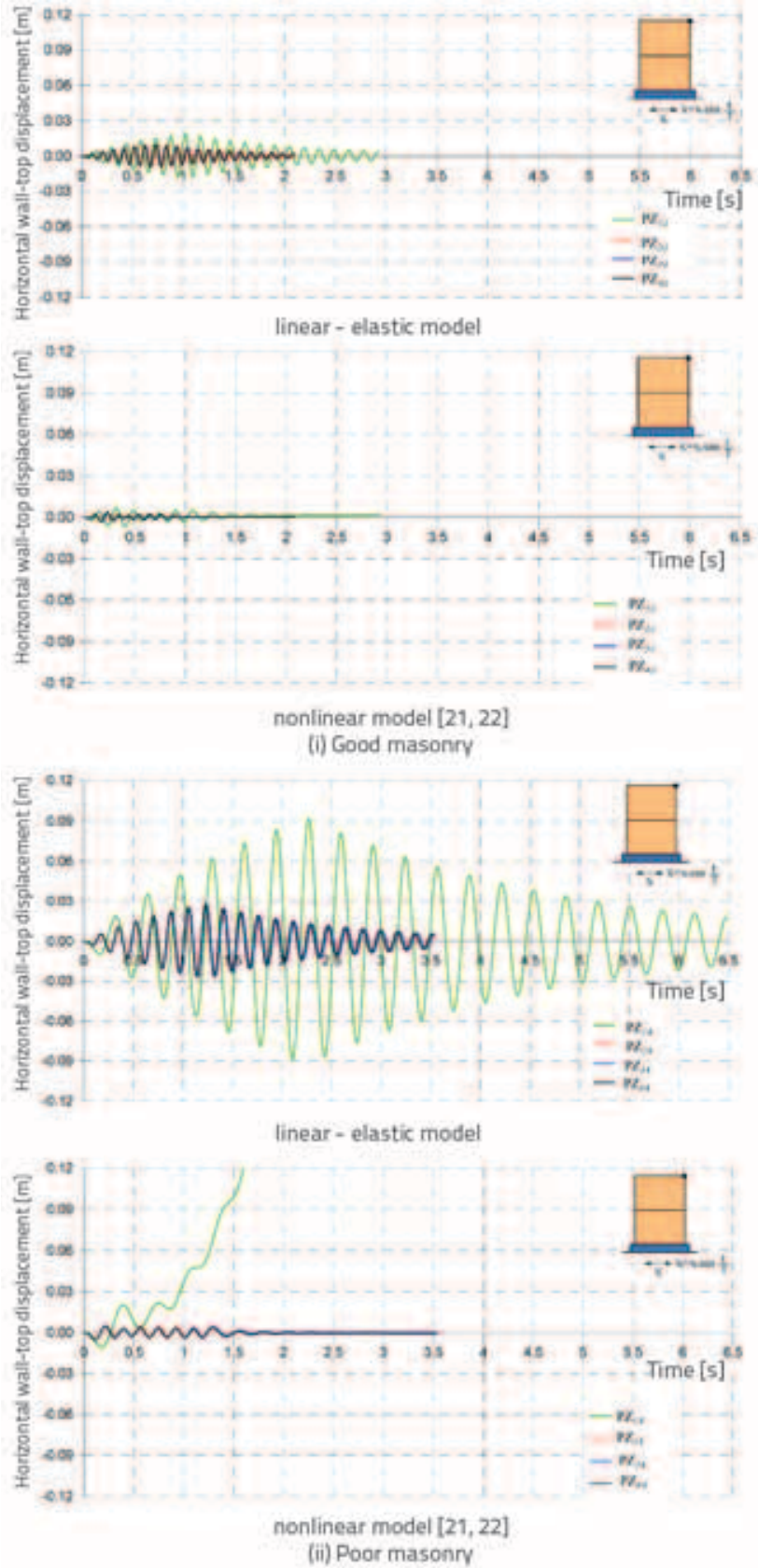

Figure 25. Horizontal wall-top displacement for walls top without openings - fixed foundation, harmonic base acceleration

vertical ring beam for the non-linear model is shown in Figure 27.

\section{Seismic base acceleration}

A dynamical analysis analogous to that presented in Item 3.2.2. b was conducted. Some of the results obtained are shown in Fig. 30-32. If comparison is made with the corresponding values of an equal wall with freely supported foundations (Fig. 17-19), it can be concluded that they are quite similar. 


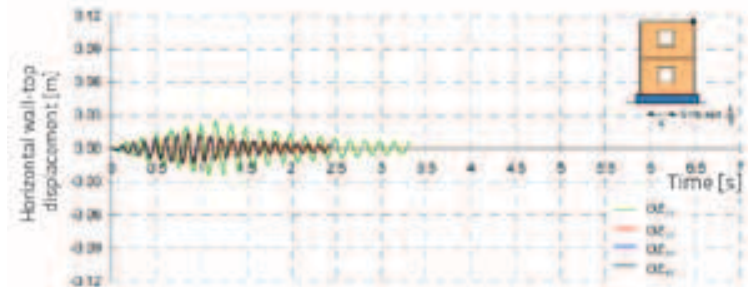

lineat- elastic model

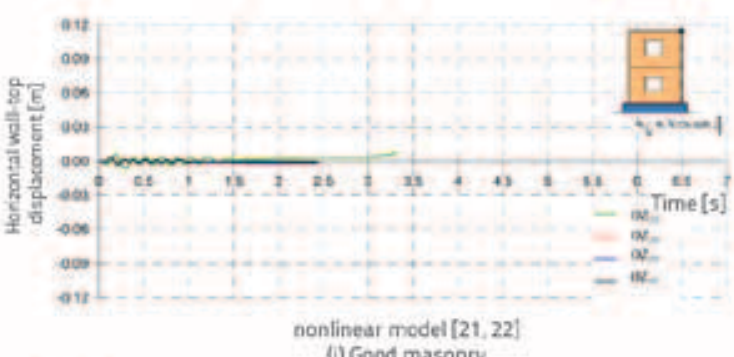

(i) Good masonry
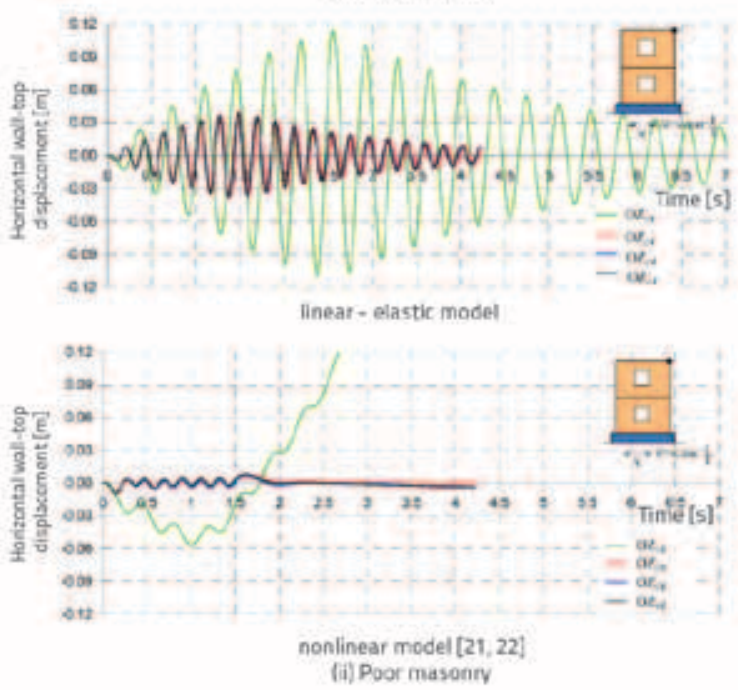

Figure 26. Horizontal displacement of walls top with openings - fixed foundation, harmonic base acceleration
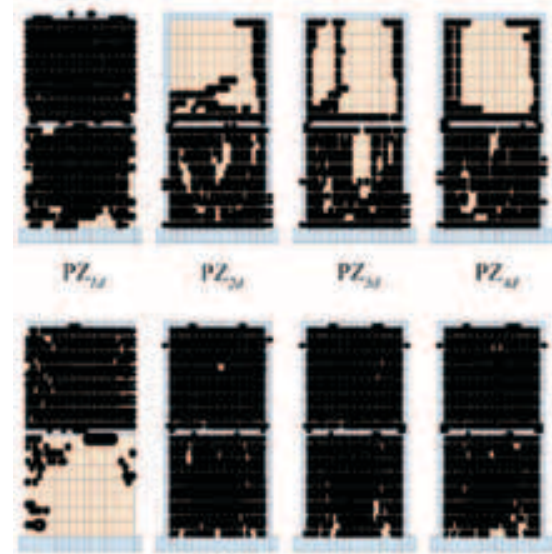

$P Z_{2}$
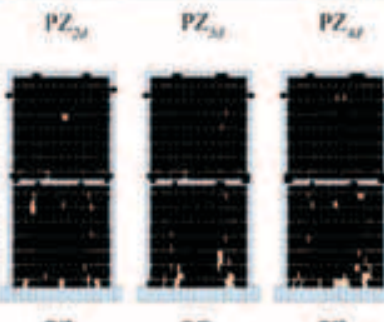

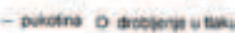

Figure 28. The state of cracks in the walls without openings after base excitation - fixed foundation, harmonic base acceleration
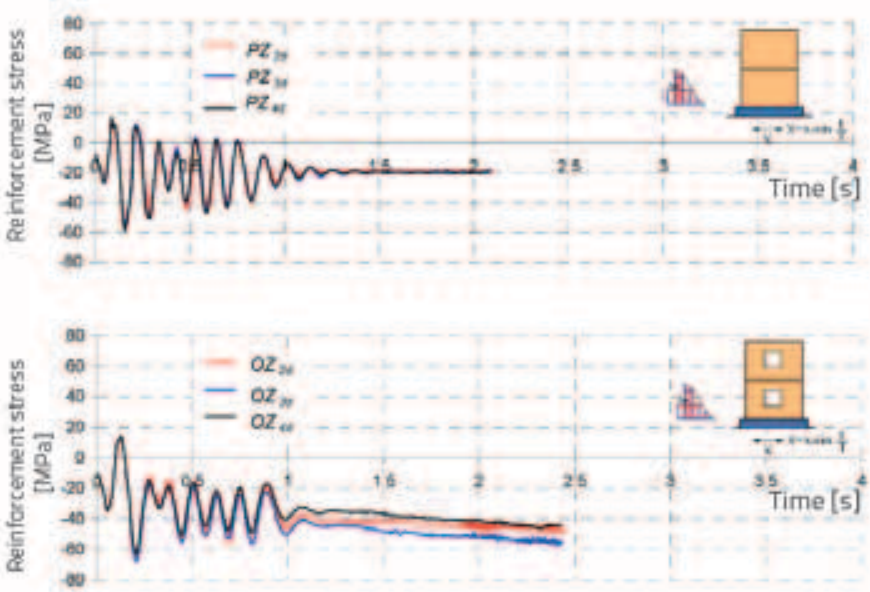

(i) Good masonry
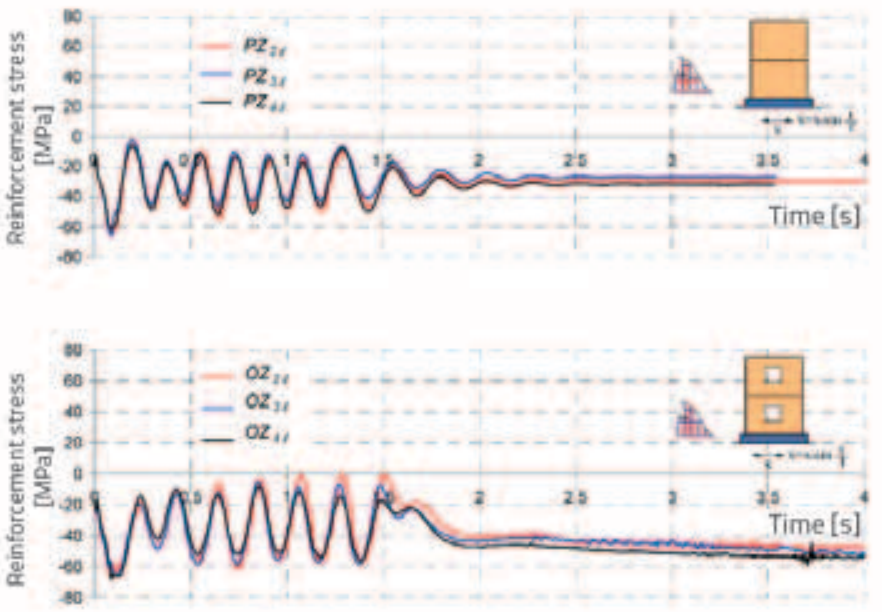

(ii) Poor masonry

Figure 27. Reinforcement stresses of vertical ring beams at the bottom of the walls - fixed foundation, harmonic base acceleration
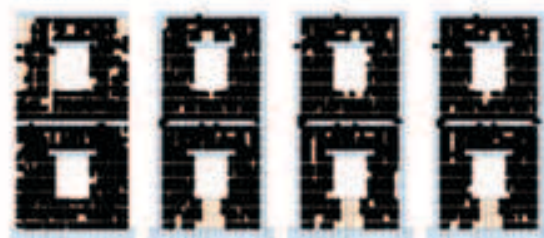

$\mathrm{OZ}$

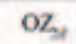

$\mathrm{OZ}$

$\mathrm{OZ}_{\mathrm{N}}$
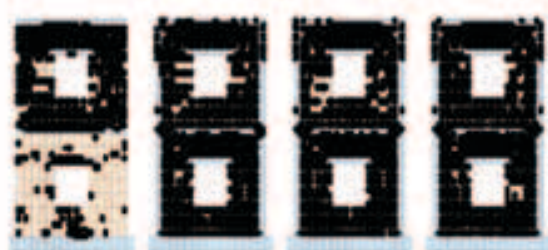

$\mathrm{OZ}_{4}$

$\mathrm{OZ}$

$\mathrm{Oz}_{v}$

oz,

Figure 29. The state of cracks in the walls with openings after base excitation - fixed foundation, harmonic base acceleration 


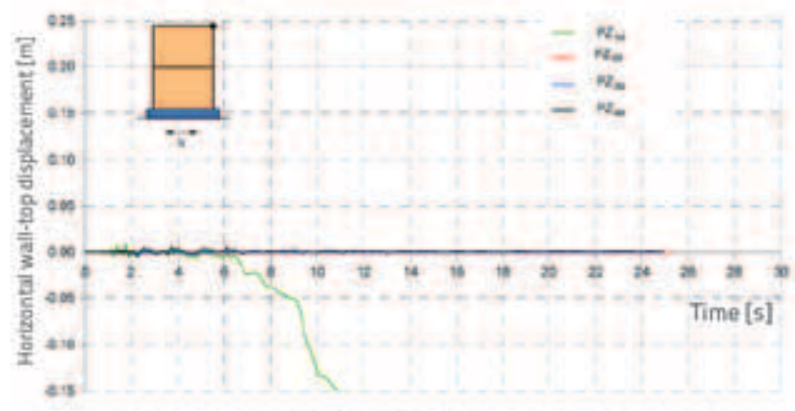

(i) Good masonry

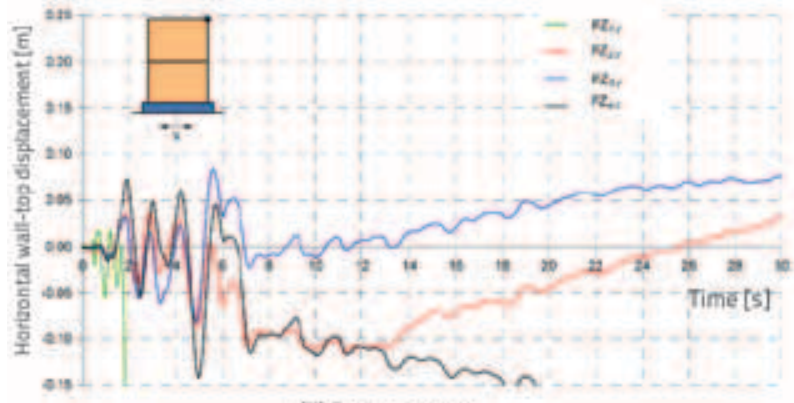

(ii) Poor masonry

Figure 30. Horizontal wall-top displacement for walls without openings - fixed foundation, seismic activity

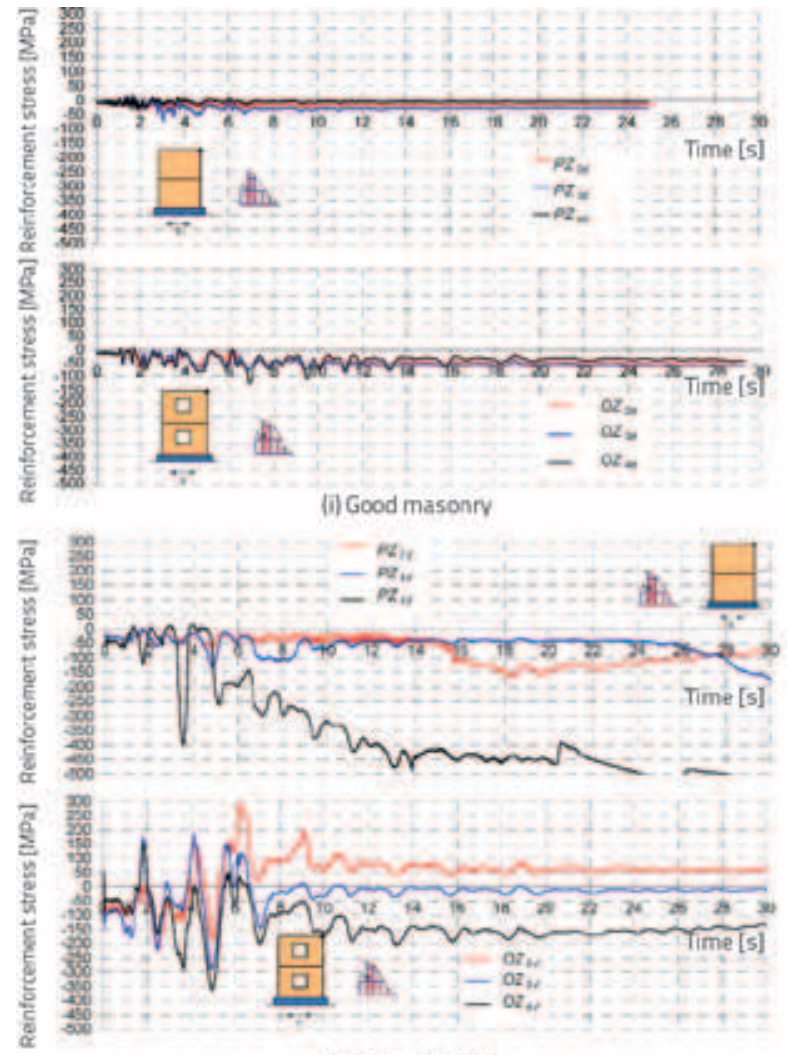

(ii) Poor masonry

Figure 32. Reinforcement stresses of vertical ring beams at the bottom of the walls - fixed foundation, seismic activity

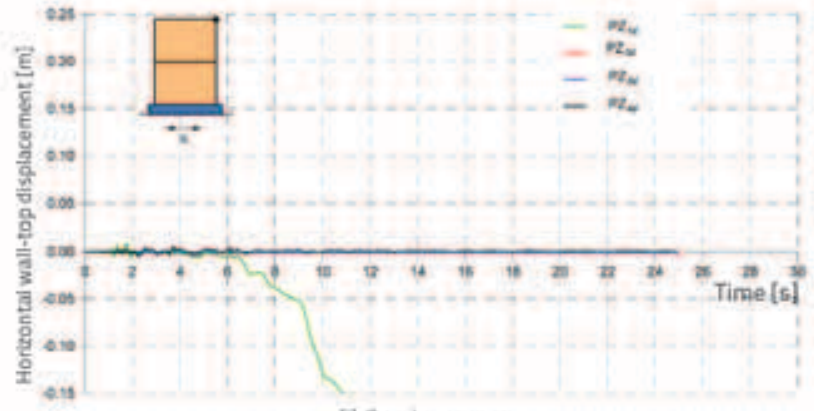

(i) Good masonry

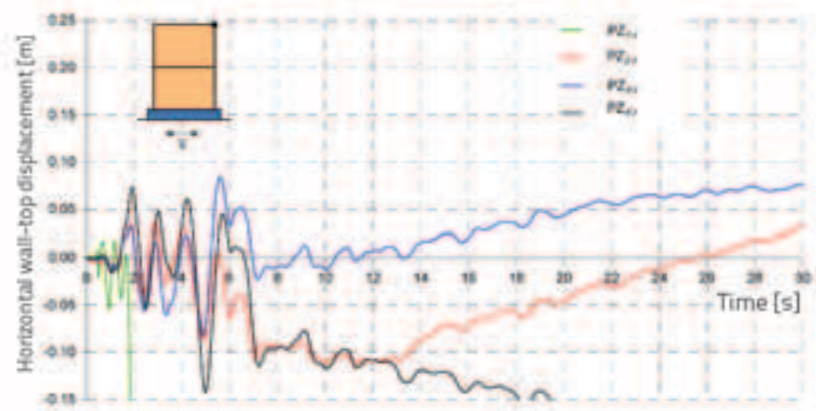

(ii) Poor masonry

Figure 31. Horizontal wall-top displacement for walls with openings - fixed foundation, seismic activity

\section{Conclusion}

The behaviour of each masonry wall under static and dynamic (seismic) load is specific and depends on many parameters. These are only global conclusions of the research, applicable to all masonry walls in real-life situations. In addition to other numerous parameters, the behaviour of masonry walls significantly depends on their total vertical load. Masonry walls with a higher total vertical load generally have a higher limit strength capacity when subjected to a horizontal static force.

When these conditions are met, the walls with possible sliding and lifting of foundations generally have significantly lower limit strength capacity than similar walls with fixed foundations. In relation to the walls without openings, walls with openings can have significantly larger displacements and a significantly lower limit strength capacity, depending on the size and position of the openings. These differences increase with the decrease in the quality of masonry. The effect of ring beams in masonry walls with openings is greater than in the walls without openings. The walls without vertical ring beams have a significantly lower limit strength capacity when compared to similar walls with vertical ring beams. Walls with stronger reinforcement of vertical ring beams (bars of larger profile) have a higher limit strength capacity for horizontal static loads and during seismic activity - especially in cases when the wall strength capacity does not depend on the loss of their stability as a rigid body (sliding, overturning). 
The effect of vertical ring beams on the strength capacity and deformability of masonry walls is higher when the quality of the masonry is lower. Longitudinal and transverse reinforcement of vertical ring beams should be designed in practice in accordance with reinforcement of pure reinforced concrete frames or reinforced concrete frames with masonry infill. The effect of real earthquakes may be less favourable than the resonant harmonic base acceleration of a similar max. acceleration.

\section{REFERENCES}

[1] Haacha, V. G.; Vasconcelos, G.; Lourenco, P. B.: "Parametrical study of masonry walls subjected to in-plane loading through numerical modeling", Engineering Structures 33, (2011) p.p.1377-1389.

[2] Milani, G.: "Simple homogenization model for the non-linear analysis of in-plane loaded masonry walls", Computers and Structures 89, (2011) p.p. 1586-1601.

[3] Mojsilović, N.: "Strength of masonry subjected to in-plane loading: A contribution", International Journal of Solids and Structures 48, (2011) p.p.865-873.

[4] Sima, J. F.; Roca, P.; Molins, C.: "Nonlinear response of masonry wall structures subjected to cyclic and dynamic loading", Engineering Structures, Vo 33, (2011) p.p. 1955-1965.

[5] Brasile, S.; Casciaro, R.; Formica, G.: "Finite Element formulation for the homogenisation of masonry", International Journal of Solids and Structures, (2009).

[6] Brasile,S.; Casciaro, R.; Formica, G.: "Multilevel approach for brick masonry walls - Part l: A numerical strategy for the nonlinear analysis", Comput. Methods Appl. Mech. Engrg. 198 (2009) p.p. 3934-3943.

[7] Brencich, A.; de Felice, G.: "Brickwork under eccentric compression: Experimental results and macroscopic models", Constraction and Building Materials 23, (2009).

[8] Mebarki, A.; Bui, Q.H.; Bui, R.; Saada, A.; Delmotte, P.; Sanchez Tizapa, S.: "A simplied mechanical model to assess the bearing capacity of masonry walls: Theory and experimental validation", Construction and Building Materials 23, (2009) p.p. 1109-1117.

[9] Chaimoon, K.; Attard, M. M.: "Modelling for unreinforced masonry walls under shear and compression", Engineering Structures 29, (2007) p.p. 2056-2068

[10] Ramalho, M.A.; Taliercio, A.; Anzani, A.; Binda, L.; Papa, E.: "Numerical model for the description of the nonlinear behaviour of multi-leaf masonry walls", Engineering Structures 29, (2007).

[11] Hashem, A.; Mosalam, K.M.: "Shake-table experiment on reinforced concrete structure containing masonry infill wall", Earthquake Engng Struct. Dyn. 35, (2006) p.p. 1827-1852.

[12] Gabor, A.; Ferrier, E.; Jacquelin, E.; Hamelin, P.: "Analysis and modelling of the in-plane shear behaviour of hollow brick masonry panels", Construction and Building Materials 20 (2006) p.p 308-321.
[13] Lourenco, P. B.; Pina-Henriques, J.: "Validation of analytical and continuum numerical methods for estimating the compressive strength of masonry", Computers and Structures 84, (2006) p.p. 1977-1989.

[14] Milani, G.; Lourenco, P.B.; Tralli, A.: "Homogenised limit analysis of masonry walls Part II: Structural examples", Computers and Structures 84, (2006) p.p. 181-195.

[15] Asteris, P.G.; Syrmakezis, C. A.: "Strenght of unreinforced masonry walls under concetrated compression loads", Practice Periodical on Structural Design and Construction, 10, (2005) p.p.133.

[16] Berto, L.; Saetta, A.; Scotta, R.; Vitaliani, R.: "Failure mechanism of masonry prism loaded in axial", Materials and Structures 38, (2005) p.p. 249-256.

[17] Cavaleri, L.; Failla, A.; La Mendola, L.; Papia M.: "Experimental and analytical response of masonry elements under eccentric vertical loads", Engineering Structures 27, (2005) p.p. 1175-1184.

[18] D. Schermer: "Experimental and numerical investigations on the behaviour of unreinforced masonry buildings under seismic loadings", 13th International Brick and Block Masonry Conference, Amsterdam, (2004).

[19] Badoux, M.; Elgwady, M.A.; Lestuzzi, P.: "Eartquake simulator tests on unreinforcedmasonry walls before and after upgrading with composites", 12 European Conference of eartquake Engineering, (2002).

[20] Tomažević, M.: "Some aspects of experimental testing of seismic behavior of masonry walls and models of masonry buildings", ISET Journal of earthquake Technology, Vol 37, (2000) p.p 101117.

[21] Radnić, J.; Harapin, A.; Matešan, D.; Trogrlić, B.; Smilović, M.; Grgić, N.; Baloević, G.: "Numerički model za statički i dinamički proračun zidanih konstrukcija", Građevinar 63, (2011.) str. 529-546.

[22] Radnić, J.; Harapin, A.; Matešan, D.; Smilović, M.; Grgić, N.: "Numerical Model for Static and Dynamic Analysis of Masonry Structure", 5th International Conference on Advanced Computational Engineering and Experimenting, Algarve, Portugal, (2011.). 